\title{
ANALISIS PERSEDIAAN KEBUTUHAN GALANGAN (PLAT KAPAL) DENGAN METODE EOQ (ECONOMIC ORDER QUANTITY) PADA PT PENGERUKAN INDONESIA
}

\section{ANALYSIS OF THE SHIPYARD INVENTORY NEEDS OF THE STEEL COIN USING EOQ'S METHOS AT PT PENGERUKAN IN- DONESIA}

Vivian Karim Ladesi a,1*, Winoto Hadi a,2, Tasya Agustin ${ }^{\text {a,3 }}$.

${ }^{a}$ Transportasi, Teknik Sipil, Universitas Negeri Jakarta, Jl. Rawamangun Muka, Jakarta Timur, Indonesia

${ }^{1 *}$ vivian_ladesi@unj.ac.id ${ }^{2}$ winoto@ @nj.ac.id ${ }^{3}$ tasyagustin5@gmail.com

\section{ABSTRACT}

Inventory is one of the fundamental problems in a business. Without inventory, a business will be faced with a variety of problems, for example, not having the option to fulfill client orders that lead to loss of client trust, inhibiting interaction creation, etc. Therefore, this study will analyze the management of ship plate inventory at PT Pengerukan Indonesia. There is a technique used to control the supply of stock, namely the "Economic Order Quantity" (EOQ) method. The method used is quantitative by using two types of data, namely primary data and secondary data. The results of this study can produce efficiency of inventory costs where the total stock of uk plate $5 \mathrm{~mm}$ company as much as 399 sheets and plate uk $12 \mathrm{~mm} 419$ sheets and companies make orders as much as 110 times a year. While using the EOQ method the company only orders the purchase of plates as many as 35 times a year with a 10-day message period with a total requirement when ordering as much as 11 pieces for uk $5 \mathrm{~mm}$ and 12 sheets for uk $12 \mathrm{~mm}$ and experience cost efficiency of Rp37,280,302. for uk 5mm plates and Rp37,673,245 for uk $12 \mathrm{~mm}$ plates.

Keywords : Analysis. Efficient, EOQ Method

\section{ABSTRAK}

Persediaan merupakan salah satu masalah mendasar dalam sebuah bisnis. Tanpa persediaan, sebuah bisnis akan dihadapkan pada berbagai masalah, misalnya, tidak memiliki pilihan untuk memenuhi pesanan klien yang menyebabkan hilangnya kepercayaan klien, menghambat interaksi penciptaan, dan lain-lain. Oleh karena itu, penelitian ini akan menganalisis manajemen persediaan plat kapal di PT Pengerukan Indonesia. Ada teknik yang digunakan untuk mengontrol pasokan stok, yaitu metode "Economic Order Quantity" (EOQ). Hasil Penelitian ini dapat menghasilkan efisiensi biaya persediaan dimana hasil Total persediaan plat uk $5 \mathrm{~mm}$ perusahaan sebanyak 399 lembar dan plat uk $12 \mathrm{~mm} 419$ lembar dan perusahaan melakukan pemesanan sebanyak 110 kali dalam setahun. Sedangkan dengan menggunakan metode EOQ perusahaan hanya memesan pembelian plat sebanyak 35 kali dalam satu tahun dengan jangka waktu pesan 10 hari dengan total kebutuhan saat memesan sebanyak 11 lembar untuk uk $5 \mathrm{~mm}$ dan 12 lembar untuk uk 12mm dan mengalami efisiensi biaya sebesar Rp37.280.302. untuk plat uk 5mm dan Rp37.673.245 untuk plat uk 12mm.

Kata Kunci : Analisis, Efisien, Metode EOQ 


\section{A. Pendahuluan}

Dalam siklus logistik, perolehan barang dagangan yang dikenal dengan pengadaan barang adalah segala jenis latihan dan upaya untuk menambah dan memenuhi persyaratan tenaga kerja dan produk yang bergantung pada pedoman yang tepat dengan membuat sesuatu yang sebelumnya tidak ada. Dalam suatu organisasi/perusahaan perolehan barang / jasa sangat penting karena berpengaruh bagi siklus berjalan suatu organisasi/perusahaan.

Dalam suatu perusaahan untuk mendapatkan suatu barang pasti melalui proses pengadaan barang, dimana pengadaan barang tersebut berpengaruh terhadap gudang. Setiap perusahaan memiliki tempat penyimpanan barang yang biasa disebut Gudang (Hadi et al., 2016) jika persediaan gudang berjalan dengan baik dan optimal maka proses logistic suatu perusahaan tersebut berjalan dengan lancar.

Bagi perusahaan, banyaknya bahan-bahan yang dapat disediakan akan menentukan besarnya penggunaan sumber-sumber dalam perusahaan tersebut (Oktora \& Verawati, 2014). Persediaan merupakan salah satu masalah mendasar dalam sebuah bisnis. Tanpa stok, sebuah bisnis akan dihadapkan pada berbagai masalah, misalnya, tidak memiliki pilihan untuk memenuhi pesanan klien yang menyebabkan hilangnya kepercayaan klien, menghambat interaksi penciptaan, dan lain-lain. Pengendalian persediaan ialah salah satu cara yang dapat dipakai guna memajukan pengeluaran oleh perusahaan dalam menyimpan bahan mentah mengingat pengendalian persediaan seperti permintaan dan kapasitas sangat penting untuk dilakukan oleh suatu perusahaan. Ketersediaan bahan baku berpengaruh pada kelancaran proses produksi perusahaan.

Kelancaran produksi itu dipengaruhi oleh bahan mentah yang diperlukan supaya selalu tersedia sehingga menjamin kelancaran proses produksi. Dikarenakan, seandainya bahan itu tidak tersedia (stock out), maka perusahaan mengalami kerugian dan perusahaan tidak dapat memasok produk secara ideal. Permintaan yang tidak pasti dan pengiriman yang selalu mendadak. Hal ini menjadikan pengiriman bahan baku dengan menggunakan transportasi udara (airfreight) yang bisa menyebablan biaya pengiriman yang menjadi mahal (Mulyati \& Verawati, 2014).

Salah satu bidang yang berpengaruh terhadap persediaan pada PT Pengerukan yaitu jasa galangan, dimana jasa galangan melayani perbaikan dan perawatan kapal. Maka dalam hal ini saya mengambil penelitian 
kebutuhan untuk jasa galangan terkhusus plat kapal dimana selama ini persediaan kebutuhan galangan PT Rukindo masih menerapkan sistem jika ada kebutuhan maka baru memesan dan masih belum menerapkan analisis dengan menggunakan metode Economic Order Quantity dalam penanganan masalah pengendalian persediaan yang terjadi pada PT Pengerukan Indonesia.

Menurut Komaruddin didalam buku Ensiklopedia Manajemen (Komaruddin, 1934). Pengertian analisis ialah kegiatan berpikir untuk menjabarkan suatu keseluruhan menjadi suatu komponen sehingga dapat mengenal hubungannya satu sama lain serta fungsi masing-masing dalam keseluruhan yang terpadu.

Kamus Bahasa Indonesia Kontemporer karangan (Salim, 2002) menguraikan pengertian tentang analisis sebagai berikut:

a. Analisis ialah mendapatkan kenyataan yang tepat (permulaan, sebab, penyebab sebenarnya, dan sebagainya) dari pemeriksaan terhadap suatu peristiwa (perbuatan, karangan dll)

b. Analisis ialah pemecahan terhadap pokok persoalan atas bagian-bagian dari penyelidikan dan berhubungan sehingga mendapatkan pemahaman yang benar dan secara menyeluruh.

c. Analisis ialah penjabaran suatu hal yang telah ditelaah secara seksama.

d. Analisis ialah tindakan berpikir kritis yang bermulai dengan spekulasi sampai dibuktikannya kevalidan melalui beberapa kepastian (persepsi, eksplorasi, dll).

e. Analisis ialah cara untuk menangani pemecahan masalah melalui akal menjadi bagian yang tergantung pada teknik sehingga dapat diprediksi untuk sampai pada pemahaman tentang standar dasarnya.

Plat kapal diproduksi menggunakan peleburan bijih besi dalam tungku sembur yang mempunyai struktur kerucut dan tungku tersebut tentunya terbuat dari bahan tahan api. Plat kapal merupakan plat yang berbeda dengan plat baja pada umumnya. Perbedaannya ialah pada kandungan unsur lain selain baja sebagai unsur utama. Unsur campuran tersebut bertujuan untuk menahan laju korosi yang terjadi pada kapal nantinya akibat pengaruh air laut. (Riki Senjaya. 2015). ship shell yang biasa disebut kulit kapal ialah permukaan kapal yang terdiri dari plat-plat baja, kayu atau aluminium yang disambung menjadi lajur yang 
terdapat pada badan kapal. Kegunaannya ialah :

1. Bisa menghasilkan kekuatan pada struktur membujur kapal.

2. Mulai dengan lajur dasar.diberi nama dengan abjad a,b,c,d dan seterusnya

3. Penutup yang kedap air dari dasar hingga bagian atas kapal.

4. Mampu menahan beban dari kapal dan muatannya.

5. Dari depan ke belakang sambungan plat diberi nama dengan angka 1,2,3 dan seterusnya

Serat kaca atau yang dikenal sebagai fiber-glass ialah bahan terbaru yang kerap dipakai dalam pembuatan kapal kecil yang banyak ditemukan dalam pelayaran pedalaman yang proses pembuatannya tidak sulit, tetapi dibutuhkan cetakan kulit lambung kapal.

Economic Order Quantity (EOQ) ialah salah satu model yang bisa dipakai guna mengawasi stok persediaan. Menurut (Slamet, 2007) diartikan sebagai pembelian dengan biaya yang minimal namun tidak menyebabkan manfaat dan beban kekurangan bahan mentah dan suku cadang tambahan. Maka kesimpulan model EOQ adalah model yang paling berpengalaman namun dalam perhitungannya sederhana dan mendasar dibandingkan dengan berbagai teknik untuk mengetahui bahan yang ideal.
Dalam bukunya, (Hansen, 2005a) menguraikan bebrapa alasan menyimpan persediaan (baik bahan baku maupun barang jadi), yang sesuai dengan aturan EOQ yaitu :

1. Melayani ketidakpastian dalam permintaan seperti adanya dugaan permintaan yang turun naik.

2. Diskon-diskon yang bisa memperoleh keuntungan.

3. Berjaga-jaga agar fasilitas manufaktur yang tidak bisa bekerja tidak menyebabkan adanya kegagalan mesin, suku cadang yang rusak, suku cadang yang tidak tersedia, dan pengiriman suku cadang yang terlambat.

4. Menghindari jika dimasa mendatang terjadi kenaikan harga

(Hansen, 2005b) mengatakan dalam metode EOQ kita dapat mengetahui berapa banyak bahan baku yang harus dipesan atau diproduksi juga dapat diketahui kapan seharusnya pemesanan dilakukan Kembali.

Adapun tujuan dari penelitian ini yaitu (1) Menganalisis pembelian plat kapal yang optimal dengan menggunakan metode analisis persediaan yaitu metode EOQ; (2) Menganalisis total biaya persediaan plat kapal yang digunakan PT Pengerukan Indonesia.

Pada penelitian sebelumnya (Tambunan et al., 2018) Metode EOQ sangat 
berpengaruh terhadap perusahaan, dikarenakan jika kelebihan atau kekurangan persediaan maka menyebabkan kerugian pada perusahaan tersebut. (Handoko, 2010) dalam bukunya memaparkan empat kategori biaya persediaan yang sangat menentukan pengoptimalan dari masalah persediaan. Empat kategori biaya tersebut ialah penyimpanan, biaya pemesanan, biaya pengadaan dan biaya stock out. Jika terjadi stock out bahan baku, maka pabrik-pabrik atau industri tidak dapat berproduksi barang sesuai jadwal yang telah ditetapkan (Verawati \& Damawaldi, 2020).

\section{B. Metode Penelitian}

Prosedur pengkajian data yang diambil penulis menggunakan pendekatan kuantitatif. Dimana pendekatan kuantitatif menggunakan Analisa berupa angka dengan melakukan Analisa tentang penerapan metode EOQ untuk manajemen persediaan kebutuhan galangan PT Pengerukan Indonesia, dalam prosedur pengkajian menggunakan data primer serta data sekunder.

\section{HASIL DAN PEMBAHASAN}

Analisis Pembelian Plat Dengan Metode EOQ

Menurut (Indriyo,Gitosudarmo, 2009) Economic Order Quantity (EOQ) ialah metode penyelesaian pengendalian stok EOQ yang umumnya digunakan meskipun dalam penerapannya digunakan asumsi berikut:

a. Mengumpulkan data tentang jumlah stok plat kapal dengan ukuran $5,00 \mathrm{~mm} \times 5^{\prime} \times 20$ dan plat uukuran $12.00 \mathrm{~mm} \times 5^{\prime} \times 20^{\prime}$

b. Dapat memahami pengendalian persediaan plat berdasarkan kebijakan perusahaan melalui data yang sudah diolah

c. Selanjutnya menganalisis data yang sudah diolah tersebut dengan memakai penerapan metode economic order quantity (EOQ)

Penggunaan metode EOQ dalam ketentuan pembelian bahan baku dapat diminimalkan kekosongan stok sehingga proses produksi dapat berjalan sesuai perencanaan. Seperti bahaya yang muncul dari pasokan bahan baku yang tertumpuk di gudang juga bisa over. Jadi untuk menentukan jumlah permintaan atau pembelian yang ideal, penting untuk memastikan jumlah pembelian ideal atau Economic Order Quantity (EOQ).(Melati \& Slamet, 2019)

Berikut langkah-langkahnya :

$$
\mathrm{EOQ}=\sqrt{\frac{2 S D}{H}}
$$


Penjelasan rumus :

EOQ = Jumlah pembelian yang optimal

$\mathrm{S}=$ Biaya pemesanan

$\mathrm{D}=$ Permintaan pertahun

$\mathrm{H}=$ Biaya Penyimpanan

Tahap utama dalam memanfaatkan teknik EOQ adalah menentukan faktor pilihan. Berdasarkan informasi yang diperoleh, pemanfaatan informasi kebutuhan plat tahun 2019 diambil dengan asumsi yaitu:

a. Yang diperhitungkan hanya satu jenis barang yaitu plat

b. Satuan barang per lembar

c. Barang yang diperlukan selalu ada dipasar.

Tabel 1. Kebutuhan Plat Kapal $5.00 \mathrm{~mm}$ x 5' x 20'

\begin{tabular}{|c|c|c|c|}
\hline No & $\begin{array}{c}\text { Berat } \\
(\mathbf{K g})\end{array}$ & $\begin{array}{l}\text { Harga } \\
\text { Per Lem- } \\
\text { bar (Rp) }\end{array}$ & $\begin{array}{c}\text { Kebu- } \\
\text { tuhan } \\
\text { (Lembar) }\end{array}$ \\
\hline Januari & 875 & 6.563 .375 & 25 \\
\hline Februari & 875 & 6.563 .375 & 32 \\
\hline Maret & 875 & 6.563 .375 & 28 \\
\hline April & 875 & 6.563 .375 & 35 \\
\hline Mei & 875 & 6.563 .375 & 33 \\
\hline Juni & 875 & 6.563 .375 & 40 \\
\hline Juli & 875 & 6.563 .375 & 43 \\
\hline Agustus & 875 & 6.563 .375 & 38 \\
\hline September & 875 & 6.563 .375 & 42 \\
\hline Oktober & 875 & 6.563 .375 & 33 \\
\hline November & 875 & 6.563 .375 & 40 \\
\hline Desember & 875 & 6.563 .375 & 30 \\
\hline & \multicolumn{2}{|c|}{ JUMLAH } & 419 \\
\hline & \multicolumn{2}{|c|}{ Rata-Rata } & 64.46154 \\
\hline
\end{tabular}

Tabel 2. Kebutuhan Plat Kapal

$12.00 \mathrm{~mm} \times 5^{\prime} \times 20$ '

\begin{tabular}{|l|c|c|c|}
\hline \multicolumn{1}{|c|}{ No } & $\begin{array}{c}\text { Be- } \\
\text { rat } \\
\text { (kg) }\end{array}$ & $\begin{array}{c}\text { Harga } \\
\text { Per } \\
\text { Lembar }\end{array}$ & $\begin{array}{l}\text { Kebu- } \\
\text { tuhan } \\
\text { (Lembar) }\end{array}$ \\
\hline Januari & 365 & 2.730 .000 & 25 \\
\hline Februari & 365 & 2.730 .000 & 28 \\
\hline Maret & 365 & 2.730 .000 & 30 \\
\hline April & 365 & 2.730 .000 & 38 \\
\hline Mei & 365 & 2.730 .000 & 33 \\
\hline Juni & 365 & 2.730 .000 & 39 \\
\hline Juli & 365 & 2.730 .000 & 35 \\
\hline Agustus & 365 & 2.730 .000 & 40 \\
\hline $\begin{array}{l}\text { Septem- } \\
\text { ber }\end{array}$ & 365 & 2.730 .000 & 30 \\
\hline Oktober & 365 & 2.730 .000 & 38 \\
\hline $\begin{array}{l}\text { Novem- } \\
\text { ber }\end{array}$ & 365 & 2.730 .000 & 30 \\
\hline $\begin{array}{l}\text { Desem- } \\
\text { ber }\end{array}$ & 365 & 2.730 .000 & 33 \\
\hline \multicolumn{3}{|c|}{ JUMLAH } & 399 \\
\hline \multicolumn{3}{|c|}{ Rata-Rata } & 33.25 \\
\hline
\end{tabular}

Berdasarkan hasil wawancara maka menghasilkan infornasi tentang pembelian yang dilakukan oleh perusahaan selama satu tahun yang dilakukan setiap bulannya dengan frekuensi pembelian satu bulan 9 kali atau 110 kali dalam satu tahun. Tabel diatas juga menampilkan jumlah per $/ \mathrm{kg}$ Plat yang dibeli perusahaan dan rincian harga setiap bulannya. Disajikan bahwa pada tahun 2019 perusahaan membeli plat ukuran 5mm x 5' x 20; sejumlah $145.635 \mathrm{~kg}$ atau 399 lembar dengan harga per/lembar Rp2.730.000 dan plat kapal ukuran $12.00 \mathrm{~mm} \times 5^{\prime} \times 20^{\prime}$ sejumlah 366.625 dengan harga per/lembar Rp6.563.375 
Biaya menyimpan sebuah barang untuk persediaan menggunakan jangka waktu satu tahun. Berdasarkan hasil observasi lapangan biayanya meliputi biaya listrik, biaya pemeliharaan alat, biaya depresiasi gudang, PBB (pajak bumi dan bangunan). Biaya berkaitan dengan pemesanan berdasarkan observasi yaitu biaya pengiriman ini meliputi sebagai berikut:

\section{Tabel 3. Biaya Simpan dan Biaya}

\section{Pemesanan}

\begin{tabular}{|l|l|}
\hline $\begin{array}{l}\text { Total Biaya } \\
\text { Pemesanan }\end{array}$ & $\begin{array}{l}\mathrm{Rp} \\
55,000,000\end{array}$ \\
\hline Total Biaya & $\mathrm{Rp}$ \\
Simpan & $1,200,000,000$ \\
\hline
\end{tabular}

Perhitungan Biaya pemesanan dan biaya simpan :

Biaya pemesanan setiap kali pesan $(\mathrm{S})$

$$
\begin{aligned}
& =\frac{\text { Total Biaya Pemesanan }}{\text { Frekuensi Pembelian }}=\frac{55.000 .000}{110} \\
& =500.000
\end{aligned}
$$

Biaya penyimpanan persatuan :

Plat Uk.5.00mm x 5' x 20'

$$
\begin{aligned}
& =\frac{\text { Total Biaya Simpan }}{\text { Total Kebutuhan }}=\frac{1.200 .000 .000}{399} \\
& =3.007 .518
\end{aligned}
$$

Plat Uk.12.00mm x 5' x 20'

$=\frac{\text { Total Biaya Simpan }}{\text { Total kebutuhan }}=\frac{1.200 .000 .000}{419}$

$$
=2.863 .961
$$

$$
\text { Perusahaan melakukan pembelian }
$$
Plat kapal dalam satu tahun dengan frekuensi pembelian 110 kali. Sehingga mengakibatkannya pengeluaran biaya pemesanan dan biaya penyimpanan. Maka dapat diketahui pengeluaran biaya pemesanannya sejumlah Rp55.000.000 dan biaya penyimpanan Rp1.200.000.000 dalam satu tahun.

Perhitungan Total Biaya Persediaan berdasarkan kebijakan perusahaan dalam mengadakan persediaan, perusahaan akan mengurangi pemesanan pada saat harga plat naik karena harga plat bergantung pada harga dollar. Kondisi ini akan mengakibatkan perusahaan wajib menangani biaya simpan yang lebih tinggi karena menimbun bahan baku di waktu tertentu. Dan diperoleh data secara lisan bahwa perusahaan melakukan pemesanan 110 kali dalam satu tahun.

Pembelian plat diperhitungkan berdasarkan kebijakan perusahaan yang melakukan pemesanan setiap bulan sekali, maka dapat diketahui sebagai berikut:

Rumus : $\frac{\text { Total Kebutuhan Bahan Baku }}{\text { Frekuensi pemesanan }}$

Plat uk 5.00mm x 5' x 20’ $=\frac{399}{110}=3.6$

Plat uk $12.00 \mathrm{~mm} \times 5^{\prime} \times 20^{\prime}=\frac{419}{110}=3.8$ 
Perhitungan jumlah pemesanan bahan baku dengan metode EOQ

Jumlah pembelian Plat Uk 5.00mm x $5^{\prime} \mathrm{x}$ 20' ekonomis (EOQ) dirumuskan sebagai berikut :

a. Total kebutuhan plat $(\mathrm{D})=399$

b. Biaya pemesanan setiap kali pesan $(\mathrm{S})=\operatorname{Rp} 500.000$

c. Biaya penyimpanan $(\mathrm{H})=\mathrm{Rp}$ 3.007 .518

Jumlah pembelian Plat Uk $12.00 \mathrm{~mm} \times 5^{\prime} \mathrm{x}$ 20' ekonomis (EOQ) dirumuskan sebagai berikut :

a. Total kebutuhan plat $(D)=419$

b. Biaya pemesanan setiap kali pesan $(\mathrm{S})=\operatorname{Rp} 500.000$

c. Biaya penyimpanan $(\mathrm{H})=\mathrm{Rp}$ 2.863 .961

Berdasarkan data di atas maka dapat dirumuskan sebagai berikut :

$$
\text { Rumus EOQ }=\sqrt{\begin{array}{c}
2 S D \\
-
\end{array}}
$$

EOQ Plat Uk 5.00mm x 5' x 20'

$=\sqrt{\begin{array}{c}2 \times 500.000 \times 399 \\ - \\ 3.007 .518\end{array}}$ $=\sqrt{\begin{array}{c}399.000 .000 \\ - \\ 3.007 .518\end{array}}$

= 11 lembar

Frekuensi pembelian $=\frac{R U}{E O Q}=\frac{399}{11}=36 \mathrm{kali}$ pemesanan

Durasi pembelian $=\frac{365}{36}=10$ hari

EOQ Plat Uk $12.00 \mathrm{~mm} \times 5^{\prime}$ x 20'

$=\sqrt{\begin{array}{c}2 \times 500.000 \times 419 \\ - \\ 2.863 .961\end{array}}$

$=\sqrt{\begin{array}{c}419.000 .000 \\ - \\ 2.863 .961\end{array}}$

$=12$ lembar

Frekuensi pembelian $=\frac{R U}{E O Q}=\frac{419}{12}=35 \mathrm{kali}$ pemesanan

Durasi pembelian $=\frac{365}{35}=10$ hari

Jika dilakukan pembelian bahan baku yang efisien dan dapat menguntungkan, perusahaan hanya melakukan pembelian plat kapal masingmasing ukuran sebanyak 36 kali dengan melakukan pemesanan setiap 10 hari dengan jumlah total persediaan plat uk $5.00 \mathrm{~m} \times 5^{\prime} \times 20^{\prime}$ sejumlah 11 lembar dan plat uk $12.00 \mathrm{~mm}$ x $5^{\prime}$ x $20^{\prime}$ sejumlah 12 lembar. sedangkan perusahaan melakukan 
pembelian 110 kali dalam satu tahun dan hanya berdasarkan perkiraan saja.

\section{Analisis Total Biaya Persediaan Plat}

Kapal (TIC)

Maka dapat diketahui data berikut ( Plat uk 5.00mm x 5' x 20') :

a. Total kebutuhan bahan baku

(D)399 lembar

b. Pembelian bahan baku per pesanan

(Q)3.6

c. Biaya pemesanan tiap kali pesan

(S)Rp500.000

d. Biaya penyimpanan

(H) Rp3.007.518

\section{Maka dapat diketahui data berikut ( Plat}

uk 12.00mm x 5' x 20') :

a. Total kebutuhan bahan baku

(D)419 lembar

b. Pembelian bahan baku per pesanan

(Q)3.8

c. Biaya pemesanan tiap kali pesan

(S)Rp500.000

d. Biaya penyimpanan

(H) Rp2.863.961
Rumus TIC $=\left(\begin{array}{c}D \\ -S \\ Q\end{array}\right)+\left(\begin{array}{c}D \\ -H \\ 2\end{array}\right)$

Plat Uk 5.00mm x 5’ x 20'

$$
\begin{aligned}
& =\left(\begin{array}{l}
399 \\
-500.000 \\
3.6
\end{array}\right)+\left(\begin{array}{c}
399 \\
-3.007 .518 \\
2
\end{array}\right) \\
& =55.416 .666+599.999 .841 \\
& =655.416 .507
\end{aligned}
$$

Plat Uk $12.00 \mathrm{~mm} \times 5^{\prime}$ x 20'

$$
\begin{aligned}
& =\left(\begin{array}{l}
419 \\
-500.000 \\
3.8
\end{array}\right)+\left(\begin{array}{c}
419 \\
-2.863 .961 \\
2
\end{array}\right) \\
& =55.131 .578+599.999 .830 \\
& =655.131 .408
\end{aligned}
$$

\section{Menentukan besarya total biaya persedi-} aan (TIC EOQ)

Menentukan besarnya biaya dalam menghitung biaya persediaan untuk pembelian bahan digunakan rumus sebagai berikut:

TIC $=$ Total Inventory Cost

Maka dapat diketahui data berikut ( Plat uk $\left.5.00 \mathrm{~mm} \times 5^{\prime} \times 20^{\prime}\right)$ :

a. Total kebutuhan bahan baku (D)399 lembar

b. Pembelian bahan baku per pesanan (Q) 11 lembar

c. Biaya pemesanan tiap kali pesan (S)Rp500.000 
d. Biaya penyimpanan (H) Rp3.007.518

$\mathrm{TIC}=\left(\begin{array}{c}D \\ -S \\ Q\end{array}\right)+\left(\begin{array}{c}Q \\ -H \\ 2\end{array}\right)$

$=\left(\begin{array}{c}399 \\ -x 500.000 \\ 11\end{array}\right)+\left(\begin{array}{c}399 \\ -x 3.007 .518 \\ 2\end{array}\right)$

$=18.136 .364+599.999 .841$

$=618.136 .205$

\section{Plat Uk 12.00mm x 5' x 20'}

1. Total kebutuhan bahan baku (D) 419 lembar

2. Pembelian bahan baku per pesanan(Q) 12 lembar

3. Biaya pemesanan tiap kali pesan (S) Rp500.000

4. Biaya penyimpanan (H)Rp2.863.961

$\mathrm{TIC}=\left(\begin{array}{c}D \\ -S \\ Q\end{array}\right)+\left(\begin{array}{c}Q \\ -H \\ 2\end{array}\right)$

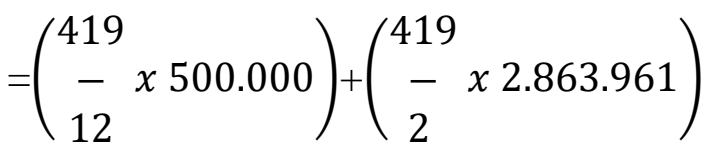

$=17.458 .333+599.999 .830$

$=617.458 .163$

Berdasarkan hasil perhitungan diatas telah diketahui dengan analisis persediaan bahan baku yang efektif maka hasil total biaya persediaan bahan baku yang harus ditanggung oleh perusahaan selama satu tahun sejumlah Rp Rp618.136.205 dengan ukuran plat 5mm dan Rp617.458.163 untuk ukuran plat $12 \mathrm{~mm}$.dan dapat di artikan bahwa hasil analisisi efesiensi biaya persediaan bahan baku mengurangi biaya-biaya persediaan sehingga perusahaan dapat mengalokasikan anggaran persediaan untuk keperluan biaya lainnya.

Efisiensi Biaya Plat Uk 5.00mm x 5'x 20'

$=$ TIC sebelum penerapan EOQ - TIC sesudah penerapan EOQ

$=\mathrm{Rp} 655.416 .507-\mathrm{Rp} 618.136 .205$

$=\mathrm{Rp} 37.280 .302$

Efisiensi Biaya Plat Uk $12.00 \mathrm{~mm}$ x 5'x 20' $=$ TIC sebelum penerapan EOQ - TIC Sesudah penerapan EOQ

$=$ Rp655.131.408 - Rp617.136.163

$=\operatorname{Rp} 37.673 .245$

Berdasarkan hasil perbandingan di atas maka diketahui efisiensi biaya plat pada perusahaan dengan total biaya persediaan seblum digunakan analisis sebesar Rp655.416.507 untuk plat uk 5mm dengan total biaya persediaan setelah digunakan analisis efisiensi persediaan yaitu sebesar Rp618.136.205 maka adanya penurunan biaya sebesar Rp37.280.302. Sedangkan plat uk $12 \mathrm{~mm}$ juga menghasilkan efisiensi biaya dengan total biaya persediaan 
sebelum menggunakan anlaisis sebesar Rp655.131.408 dengan total biaya persediaan setelah digunakan analisis efisiensi sebesar Rp617.136.163 sehingga mengalami penurunan biaya juga sebesar Rp37.673.245.

\section{SIMPULAN}

Berdasarkan hasil analisis data yang dibahas pada bab sebelumnya maka dapat disimpulkan hasil dari penelitian yang telah dilakukan adalah sebagai berikut :

1. Penerapan metode economic order quantity (EOQ) pada PT Pengerukan Indonesia dapat menghasilkan efisiensi biaya persediaan dan dapat disimpulkan bahwa penerapan kebijakan saat ini untuk persediaan barang belum efisien dan tidak menghasilkan biaya yang minimum. Hasil Total persediaan plat uk $5 \mathrm{~mm}$ perusahaan sebanyak 399 lembar dan plat uk 12mm 419 lembar dan perusahaan melakukan pemesanan sebanyak 110 kali dalam setahun. Sedangkan dengan menggunakan metode EOQ perusahaan hanya memesan pembelian plat sebanyak 35 kali dalam satu tahun dengan jangka waktu pesan 10 hari dengan total kebutuhan saat memesan sebanyak 11 lembar untuk uk 5mm dan 12 lembar untuk uk $12 \mathrm{~mm}$
2. Total biaya persediaan sebelum digunakan analisis sebesar Rp655.416.507 untuk plat uk 5mm dengan total biaya persediaan setelah digunakan analisis efisiensi persediaan yaitu sebesar Rp618.136.205 maka adanya penurunan biaya sebesar Rp37.280.302. Sedangkan plat uk $12 \mathrm{~mm}$ juga menghasilkan efisiensi biaya dengan total biaya persediaan sebelum menggunakan anlisis sebesar Rp655.131.408 dengan total biaya persediaan setelah digunakan analisis efisiensi sebesar Rp617.136.163 sehingga mengalami penurunan sebesar Rp37.673.245.

\section{E. DAFTAR PUSTAKA}

Hadi, W., Karsafman, T., \& Jodi, A. (2016). Proses Gudang 007 Pada Terminal Operasi I PT . Pelabuhan Indonesia II Dengan Menggunakan Metode First InFirst Out. IX, 33.

Handoko, H. (2010). Manajemen Personalia \& Sumberdaya Manusia, Edisi kedua. BPFE UGM.

Hansen, D. R. and M. M. M. (2005a). Akuntansi Manajemen (Buku 2 Edi). Salemba Empat.

Hansen, D. R. and M. M. M. (2005b). Akuntansi Manajemen (Buku 2 Edi). Salemba Empat.

Indriyo,Gitosudarmo. (2009). Manajemen Operasi (Edisi 3). BPFE-YOGYAKARTA.

Komaruddin. (1934). Ensiklopedia manajemen : berisi 4907 entri. Bumi Aksara. 
Melati, M., \& Slamet, A. (2019). Management Analysis Journal. 8(4).

Mulyati, E., \& Verawati, K. (2014). Pesawat Terbang Untuk Meminimasi Total Biaya Inventory. E-Mail: Rna_rian@yahoo.Com J@TI Undip, 10(2),99-104.

Oktora, A., \& Verawati, K. (2014). PENENTUAN JADWAL PEMESANAN MATERIAL PEMBENTUK KOMPONEN PESAWAT TERBANG UNTUK MEMINIMASI TOTAL BIAYA. 4(2), 51-58.

Salim, P. dan Y. Salim. (2002). Kamus Bahasa Indonesia Kontemporer. Modern English Press.

Slamet, A. (2007). Penggangaran Perencanaan dan Pengendalian Usaha. UNNES PRESS.

Tambunan, E., Matematika, D., Matematika, F., Ilmu, D. A. N., Alam, P., \& Utara, U. S. (2018). Penerapan Metode Economic Order Quantity ( EOQ ) Dalam Optimalisasi Persediaan Alumina ( Studi Kasus : PT . Indonesia Asahan Aluminium ).

Verawati, K., \& Damawaldi, D. O. (2020). Optimalisasi Tempat Penyimpanan Terbuka Kendaraan di PT Indonesia Kendaraan Terminal Jakarta Optimization of Open Storage' s Vehicles in PT Indonesia Kendaraan Terminal Jakarta. Manajemen Transportasi \& Logistik, 07(03), 11. 